of devices for paraphrasing (pp. 35-43) ; but Bednara's pages make one realise how supremely important is a thorough acquaintance with the morphology of Ovidian verse. Briefly to state Bednara's plan. Founding his work on the observetions of Koene (1840), but avoiding some of his fallacies, he subjects the Amores and Ars Amatoria of Ovid (perhaps he should have added the Heroides) to a thorough scrutiny. His aim is to demonstrate the devices by which Catullus and Ovid surmounted the difficulties which the Latin language put in the way of dactylic composition. The first of his three main sections deals with words metrically unfitted for dactylic verse. The second treats of the solutions which the poets found for their difficulties, solutions connected with such points as order of words, elision, etc.; with shortening and lengthening of vowel sounds; with the use of alternative forms; the adjustment of syntax (as of number, gender, mood, and tense) to verse needs; and with 'remedia lexicalia,' that is, the adoption of synonyms or coining of new words so as to dispense with inconvenient words. 'Ea (vocabula) quae non quadrabant, seponebantur, et saepe exilibus quasi artificiis et argutiis pro iusto verbo minus iustum, tamen dactylicum eligebatur' (Ploen). This second section is worked out clearly and thoroughly, and many interesting topics are treated by the way, but especially to be commended is the thorough examination of the subject of poetic plurals (pp. 50-79). In his third section the author sums up. His finding is that Catullus is not influenced by metrical necessity nearly so much as Ovid: 'sermo Catullianus magis est naturalis atque genuinus quam Ovidi.' ' Ovidius multo audacior est in vocabulis transponendis et in prosodia vocum mutanda, ... Graecis flexionibus multo magis indulget, multo frequentius et licentius plurali (item singulari) poetico utitur, ... multo plures adhibet periphrases, multo plura dactylica vocabula vel inventa recepit vel ipse invenit.'

S. E. WINBOLT.

\title{
OBITUARY
}

\author{
DR. JAMES ADAM.
}

James AdAM was born in Aberdeenshire in 1860 . He was educated at the Grammar School and' University of Aberdeen, and in 1880 came to Cambridge as a scholar of Gonville and Caius. After his degree in r884 he was elected fellow and became lecturer of Emmanuel, and he had no small share in the rapid growth of that college in reputation. He at once began to give his attention to Plato, compiling excellent school editions of the Apology, Crito, and Euthyphro. For the next twelve years he was engaged in preparing for his edition of the Republic; in I891 he published a paper on the Nuptial Number, and in 1897 an edition of the text. For the elaborate commentary of 1902 he had searched practically the whole of Platonic literature, neglecting no bundle of chaff which might contain a grain of corn. A volume of essays on the text and matter of the Republic was left for posthumous publication, together with his Gifford lectures on the Religious Teachers of Greece. As a lecturer he was stimulating in a high degree, and his lectures were favourites with all sorts and conditions of men. His death followed suddenly after an operation on August $3^{\circ}$, and is an irreparable loss to scholarship. His personal qualities, which made him a staunch friend, and a trusted guide, will be no less missed in the University.

\section{PROFESSOR STRACHAN.}

ThE death of Prof. John Strachan at the early age of forty-five after only a short illness, is a grievous loss, not merely to Keltic learning, in which his acute and monumental research had made him one of the first authorities of our time, but also to the study of Greek. He was one of a group of eager Scotch students who owed their enthusiasm for study and a distinguished career in the. world of learning to the inspiration of the 
University of Aberdeen when Sir William Geddes was its Professor of Greek. He was fellow-stadent of Dr. P. Giles and the late Dr. James Adam in the Classical Honours Classes of that University from i 878 to $188 \mathrm{r}$, and having won the Fullarton Scholarship at Aberdeen, and the coveted Ferguson Scholarship, he entered as a Scholar at Pembroke College, Cambridge, in r882. His career at Cambridge was marked among other distinctions by the Porson University Scholarship and the and Chancellor's Medal. With somewhat unusual liberality and foresight, the authorities of his College allowed him to spend a considerable part of his last two years in studying Comparative Philology and Keltic under Delbrück, Thurneysen, and other leaders of the new School of Philology in Germany; and this gave him a deep interest in linguistic study, which bore remarkable fruit.

Almost immediately after taking his degree at Cambridge, he was appointed Professor of Greek at, what was then the Owens College and is now the University of Manchester; and to this he added in 1889 the Lectureship in Comparative Philology, and in 1905 a Readership in Keltic, which was on the eve of being transformed into a full Professorship to meet the needs of the rapidly growing School of Keltic Studies which he had founded, when his tragically sudden death put an end to these hopes cherished so long and promising so brightly.

His contributions to Greek Scholarship were overshadowed in later years by his devotion to Keltic, but they were of no common order. Apart from a number of Philological notes on different points in Greek, his edition of the Sixth Book of Herodotus in r89r, though designed primarily for the use of students rather than scholars, is distinguished from its companion volumes by $\mathbf{a}$ first hand mastery of all the sources of knowledge both of the language and of the subject-matter, and no one who has used it will readily forget the stimulating freshness and independence of the Commentary. At his death he left behind practically complete a Historical Grammar of Greek which he had undertaken for the Clarendon Press.

As a teacher of Greek his success lay with small classes of able students whom he inspired with his own enthusiasm. In , his last year at Manchester, he had gathered together a class of six students to spend two hours a week with him in reading Sanskrit, one of whom has since proceeded to Cambridge holding a Research Scholarship.

His fame will rest on his great service to Keltic learning, especially as joint-editor of the Thesaurus Palaeohibernicus, which brought light into a thousand dark places ; and by his contribution to the dating of the documents of Old Irish by linguistic evidence. His memory will live long in the grateful recollections of many students, who first learnt from him that language is a living thing with a history and a romance of its own; and in the deep, affectionate regret of a multitude of colleagues, who knew in him a genial, loyal, warm-hearted companion, of high ideals. and chivalrous sympathy with other men's endeavours, whose like they will not expect to meet again.

\section{R. S. Conway.}

\section{ADOLF FURTWÄNGLER.}

Professor Furtwängler died in hospital at Athens on IIth October last. $\mathrm{He}$ was busy with his friend Curtius on the excavations at Aegina, when both explorers were seized with dysentery. "The one was taken and the other left.' As he was born (at Freiburg in Breisgau) in 1853 , he was but
54 years old ; but labours such as his might have undermined any constitution.

It is difficult to exaggerate the blank which his loss will make in archaeology. From 1874, when he published Eros in der Vasenmalerei, down to the time of his death, he poured forth a constant stream of learned 